\title{
DOZUOTO FIZINIO KRŪVIO POVEIKIS PAAUGLIŲ SKELETO RAUMENŲ SISTEMAI
}

\author{
Tomas Aukštikalnis ${ }^{1,2}$, Veslava Radzevič ${ }^{1,2}$, Ernesta Godliauskiené2, Rita Urbanavičée ${ }^{1,2}$, \\ Jonas Kairys ${ }^{1,2}$, Juozas Raistenskis ${ }^{1,2}$ \\ ${ }^{1}$ Vaiku ligonine, Vilniaus universiteto ligoninès Santaros kliniku filialas, \\ ${ }^{2}$ Vilniaus universiteto Medicinos fakulteto Sveikatos mokslu institutas
}

Raktažodžiai: dozuotas fizinis krūvis, veloergometras, paaugliai, skeleto raumenų sistema.

\begin{abstract}
Santrauka
Tyrimo tikslas - ištirti dozuoto fizinio krūvio poveiki paauglių skeleto raumenų sistemai.

Tyrimas buvo vykdomas $2018 \mathrm{~m}$. kovo - $2019 \mathrm{~m}$. sausio mėnesiais Vilniaus Senvagès gimnazijoje ir Vaikų ligoninejje, viešosios įstaigos Vilniaus universiteto ligoninès Santaros klinikų filiale. Tyrime dalyvavo 14-17 metų paaugliai, kurie savanoriškai sutiko dalyvauti tyrime. Tiriamųų imti sudare 46 mokiniai, iš kurių -27 merginos ir 19 vaikinų. Mokinių kojų raumenų jègos bei dinaminès ištvermès vertinimui naudotas izokinetinis dinamometras „Biodex multijoint system 4-pro“, o ūgiui ir bendrajai kūno masei nustatyti - medicininès svarstyklès. Dozuoto fizinio krūvio intervencijos poveikiui tirti naudotas veloergometras. Statistinei duomenų analizei atlikti buvo naudojamos MS Excel 2016 ir SPSS Windows 17.0 programos.
\end{abstract}

Rezultatai. Dviejų mènesių trukmès dozuoto fizinio krūvio taikymas padidino maksimalią jègą, jègos ir kūno masès santykị bei nuveiktą darbą $(\mathrm{p} \leq 0,05)$. Praejjus dviejų mėnesių trukmès intervencijos taikymui, papildomai du ménesius laikantis fizinio aktyvumo rekomendacijų, pasiekti skeleto raumenų jègos ir dinaminès ištvermès rezultatai neregresavo $(\mathrm{p} \leq 0,05)$. Atitinkamai, keturis mènesius taikant vienodą dozuotą fizinị krūvị, taip pat padidèjo skeleto raumenu jèga ir dinaminè ištvermè $(p \leq 0,05)$, tačiau nuo antro intervencijos ménesio raumenų jègos ir dinaminès ištvermès didejjimo tendencija nebuvo statistiškai reikšminga ( $p>0,05)$. Taikant dviejų ir keturių mènesių trukmès intervenciją, agonistų ir antagonistų santykis tyrimo eigoje nepakito $(p>0,05)$. Lyginant fizinio krūvio poveiki abiem tiriamųjų grupėms, pastebèta, kad po dviejų mènesių intervencijos, jègos ir kūno masès santykis buvo didesnis, nei tos grupès, kuriai buvo taikyta keturių mėnesių trukmès intervencija $(\mathrm{p} \leq 0,05)$. Tiriamujų grupei, kuriai buvo taikyta keturių mènesių trukmès intervencija, agonistų ir antagonistų santykis pirmojo ir antrojo tyrimo metu buvo didesnis, nei tos grupès, kuriai buvo taikyta dvieju mėnesių trukmès intervencija ( $\mathrm{p} \leq 0,05)$, tačiau skirtumų tarp kitu jègos ir dinaminès ištvermès rodiklių nenustatyta $(\mathrm{p}>0,05)$.

Išvados. Dviejų mėnesių trukmès dozuoto fizinio krūvio taikymas vienodai padidino skeleto raumenų jègą ir dinaminę ištvermę agonistams ir antagonistams. Du mènesius namuose laikantis fizinio aktyvumo rekomendacijų, skeleto raumenų jègos ir dinaminès ištvermès rezultatai neregresavo. Keturių mėnesiu trukmès dozuoto fizinio krūvio taikymas vienodai padidino skeleto raumenų jègą ir dinaminę ištvermę agonistams ir antagonistams, tačiau nuo antro intervencijos mènesio raumenų jègos ir dinaminès ištvermès didejjimo tendencija nebuvo statistiškai reikšminga. Ir keturių mènesių trukmès dozuoto fizinio krūvio taikymas, ir dviejų mėnesių intervencija, po kurios du ménesius namuose laikytasi fizinio aktyvumo rekomendacijų, vienodai padidino raumenų jègos ir dinaminès ištvermès rodiklius.

\section{Ivadas}

Fizinis aktyvumas jaunysteje padeda sukurti sveiko ir produktyvaus gyvenimo pagrindus ateityje [1]. Vis dèlto pasaulyje pastebima fizinio aktyvumo mažejimo tendencija $[2,3]$. Jaunų žmonių judejjimo stoka veikia jų fizinę, emocinę ir psichologinę savijautą. Mažèjant fizinio aktyvumo rodikliams, vis daugiau paauglių skundžiasi ịvairiais sveikatos sutrikimais, prasta emocine savijauta. Viena dažniau- 
siai ịvardijamų sumažèjusio judrumo priežasčių - pakitęs šiuolaikinès visuomenès požiūris ị fizinị aktyvumą, socialinių, kultūrinių ir ekonominių veiksnių kitimo procese [4]. Technologijų pažanga išsivysčiusiose šalyse pakeite žmonių gyvenimo būdą - jis tapo sèslesnis. Dèl to smarkiai padaugèjo netaisyklingos laikysenos, širdies ir kraujagyslių sistemos sutrikimų, padidejjo ankstyvos mirties tikimybè, išaugo neužkrečiamujų lètinių ligų ir kardiometabolinio sindromo atvejų bei kognityvinių sistemų pakitimo skaičiai, suprastèjo paaugliu gyvenimo kokybė $[4,5]$. Reguliaraus fizinio aktyvumo nauda kultūriniam, socialiniam ir psichologiniam gyvenimui, skeleto ir raumenų sistemai yra įrodoma gausiai atliekamuose tyrimuose [6].

Jau ilgą laikotarpi trunkantys skeleto ir raumenų sistemos, jos svarbos žmogaus organizmui moksliniai tyrimai, kasmet gilinami ir papildomi, siekiant kuo geriau suvokti skeleto ir raumenų sistemos veikimą bei jos sąsajas su kitomis organizmo sistemomis $[7,8]$. Skeleto ir raumenu sistema susijusi ir su kitomis organizmo sistemomis. Raumenys dalyvauja termoreguliacijos procese, palaikydami kūno temperatūrą, laikyseną, padėdami reguliuoti širdies ir kraujagyslių bei kvėpavimo sistemų veiklą. Nustatytas ryšys tarp skeleto raumenų masès ir medžiagų apykaitos sistemų [7,9]. Fizinis aktyvumas paauglystejje tiesiogiai didina mineralinių medžiagų kiekị kauluose, jaunystèje - padeda išlaikyti esamą jų kiekį, o vyresniame amžiuje lètina šių medžiagų mažejimo tempą $[10,11]$. Mokslininkai teigia, kad siekiant padidinti kaulų mineralinị tankị, ypač svarbu tai daryti paauglystès metais. Ilgalaikis ir pastovus fizinis aktyvumas apie dvidešimtuosius gyvenimo metus leidžia pasiekti didžiausią kaulinio audinio masę, o nuo skeleto ir raumenų fiziologinio išsivystymo priklauso paauglio laikysena [12]. Daugelis mokslininkų teigia, kad paauglių, turinčių laikysenos sutrikimų, skaičius didejja ir kelia vis didesnį sveikatos priežiūros institucijų susirūpinimą [13-16]. Dažniausiai ịvardijamos laikysenos sutrikimų priežastys yra raumenų nepakankamas išsivystymas, jų nusilpimas, fizinio aktyvumo stoka [14]. Dèl šiu priežasčių nukenčia skeleto ir raumenu fizinis pajėgumas, vystosi netaisyklinga, dažnai kompensacinè kūno laikysena, todèl labai svarbu atkreipti dèmesị ị taisyklingo fizinio aktyvumo programos parinkimą ir krūvio dozavimą [13].

Taikant fizinị krūvị, labai svarbus yra jo dozavimas, padedantis suprasti fizinio aktyvumo ir sveikatos rezultatų asociacijas, reikalingas atrasti ir ištirti fizinio aktyvumo poveiki organizmui [17]. Mokslinių tyrimų duomenimis, dozuotas fizinis krūvis teigiamai veikia psichoemocinę būklę, pažintinius gebejjimus, mokymosi pasiekimus ir įvairias organizmo sistemas, tokias kaip širdies ir kraujagyslių, nervų, skeleto ir raumenų, imuninè [18 - 23]. Didžiają dalị teigiamų rezultatų lemia nuoseklus fizinio krūvio planavimas, kuriuo siekiama ji efektyviausiai panaudoti $[24,25]$. Netinkamai dozuojant arba ribojant fizinị krūvị, dažnai galima pastebèti išsivysčiusią skeleto raumenų sistemos rodiklių regresiją [26-28]. Mažas fizinio aktyvumo lygis bei staigus perejimas prie sėsliojo gyvenimo būdo, ypač po reguliarios aktyvios fizinès veiklos laikotarpio, turi didelį neigiamą poveikị skeleto raumenų sistemai $[27,29]$, todèl ypač svarbus kasdienis fizinis aktyvumas, laikantis fizinio aktyvumo rekomendacijų, kurios atitinkamo amžiaus grupėms yra skirtingos.

Tyrimo tikslas - ištirti dozuoto fizinio krūvio poveikị paauglių skeleto raumenų sistemai.

\section{Tyrimo objektas ir metodika}

Tyrimas buvo vykdomas $2018 \mathrm{~m}$. kovo - $2019 \mathrm{~m}$. sausio mėnesiais Vilniaus Senvagès gimnazijoje. Tyrime dalyvavo atsitiktinès atrankos metodu atrinkti 14-17 metų paaugliai, kurie savanoriškai sutiko dalyvauti tyrime. Tiriamujų imti sudare 46 aštuntų-vienuoliktų klasių mokiniai, iš kurių 27 (58,7 proc.) merginos ir 19 (41,3 proc.) vaikinų. Amžiaus vidurkis $15 \pm 0,83$ metų: merginų $15 \pm 0,83$, vaikinų $15 \pm 0,84$. Tyrime dalyvavo paaugliai, kurie atitiko ịtraukimo ị tyrimą kriterijus: 1) sutinkantys ir pateikusieji raštišką tèvų sutikimą; 2) 14-17 metų sveiki paaugliai. Neįtraukimo ị tyrimą kriterijai: 1) aktyviai sportuojantys paaugliai; 2) širdies susitraukimų dažnis ramybès metu daugiau kaip $85 \mathrm{k} . / \mathrm{min}$.

Tyrimo metu buvo naudojami du veloergometrai (Ergocard II), tam tikslui patalpinti Vilniaus Senvagès gimnazijos medicinos punkto patalpose, izokinetinis dinamometras „Biodex multi-joint system 4-pro“ ir medicininès svarstyklès (elektron/M-100), kuriose integruota ištraukiamoji ūgio matuoklè. Tiriamieji buvo suskirstyti ị pirmają ir antrają eksperimentines grupes po 23 paauglius. Pirmajai eksperimentinei grupei dozuoto fizinio krūvio procedūros veloergometru vyko du mènesius, tris kartus per savaitę, po 30 minučių, 150 W intensyvumu. Šiai grupei po dviejų mènesių dozuoto fizinio krūvio procedūrų buvo pateiktos PSO fizinio aktyvumo rekomendacijos, kuriu tiriamieji turejo laikytis namuose dar du mènesius. Antrajai grupei keturis mènesius buvo taikytos tos pačios dozuoto fizinio krūvio procedūros veloergometru.

Dozuotą fizinị krūvị sudarẻ trys dalys - ịvadinè, pagrindinè ir baigiamoji. İvadinès dalies ( 5 min.) tikslas - suaktyvinti širdies ir kraujagyslių sistemos funkcijas, paruošti organizmą tolesniam fiziniam krūviui. Tiriamieji buvo patogiai pasodinami ant veloergometro, sèdynès aukštis sureguliuojamas taip, kad apatiniame pedalo taške kelis būtų šiek tiek sulenktas. Pradžioje buvo taikomas penkių minučių apšilimas, minant veloergometrą $25 \mathrm{~W}$ galingumu, kas minutę didinamu $25 \mathrm{~W}$. Pagrindinès dalies (20 min.) tikslas - apatinių galūnių raumenų jègos ir dinaminès ištvermès lavinimas. Dozuoto 
fizinio krūvio procedūros su veloergometru atliekamos vidutiniu $150 \mathrm{~W}$ intensyvumu, trukmè - 20 minučių. Baigiamosios dalies (5 min.) tikslas - normalizuoti organizmo apkrovimą, atpalaiduoti raumenis, normalizuoti ŠKS funkcijas. Šioje dalyje tiriamieji turejjo minti veloergometrą penkias minutes, kas minutę mažindami krūvị po $25 \mathrm{~W}$, bei atlikti kvėpavimo pratimus.

Tyrimas buvo atliekamas tris kartus - prieš dozuoto fizinio krūvio intervenciją, po dviejų ir keturių mènesių intervencijos. Prieš pirminį skeleto raumenų būklès įvertinimą buvo atliekamas ūgio ir svorio matavimas, naudojant medicinines svarstykles (elektron/M-100), kuriose integruota ištraukiamoji ūgio matuoklè. Šie parametrai buvo matuojami tik tyrimo pradžioje. Tiriamujų skeleto raumenų būklè buvo vertinama

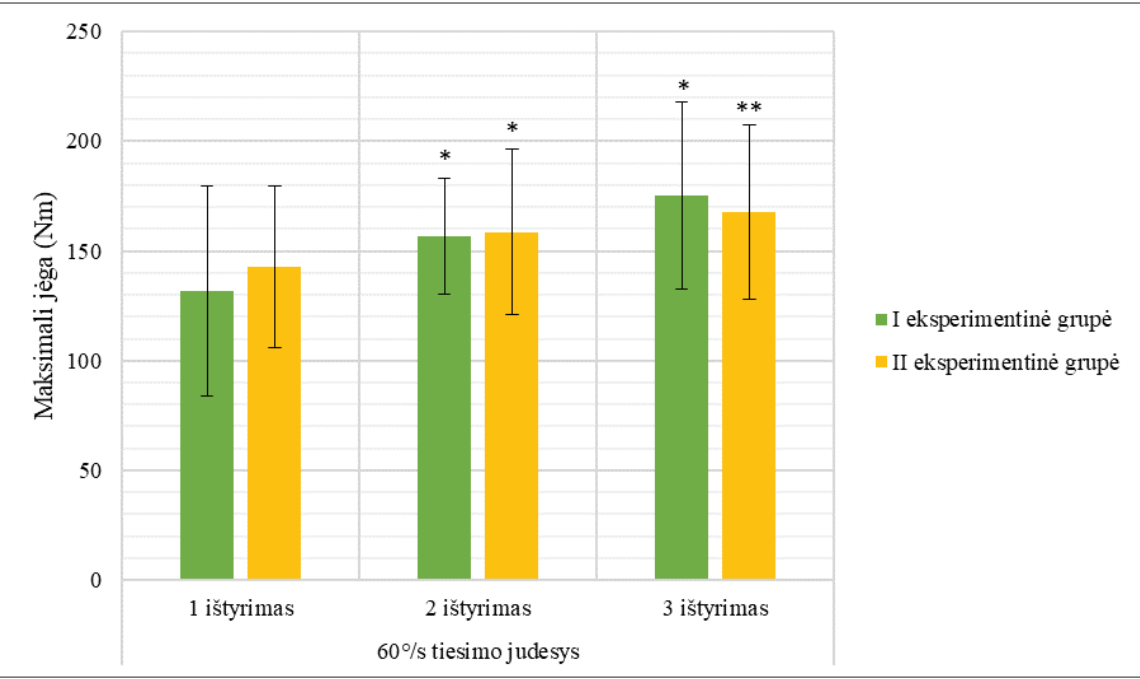

1 pav. I ir II eksperimentinių grupių maksimalios jẻgos pokytis, atliekant kelio sąnario tiesimo judesi $60 \%$ s kampiniu greičiu.

${ }_{*}^{*} \leq \leq 0,05$, lyginant su 1 tyrimu; ** $p \leq 0,05$, lyginant su 1 ir 2 tyrimais.

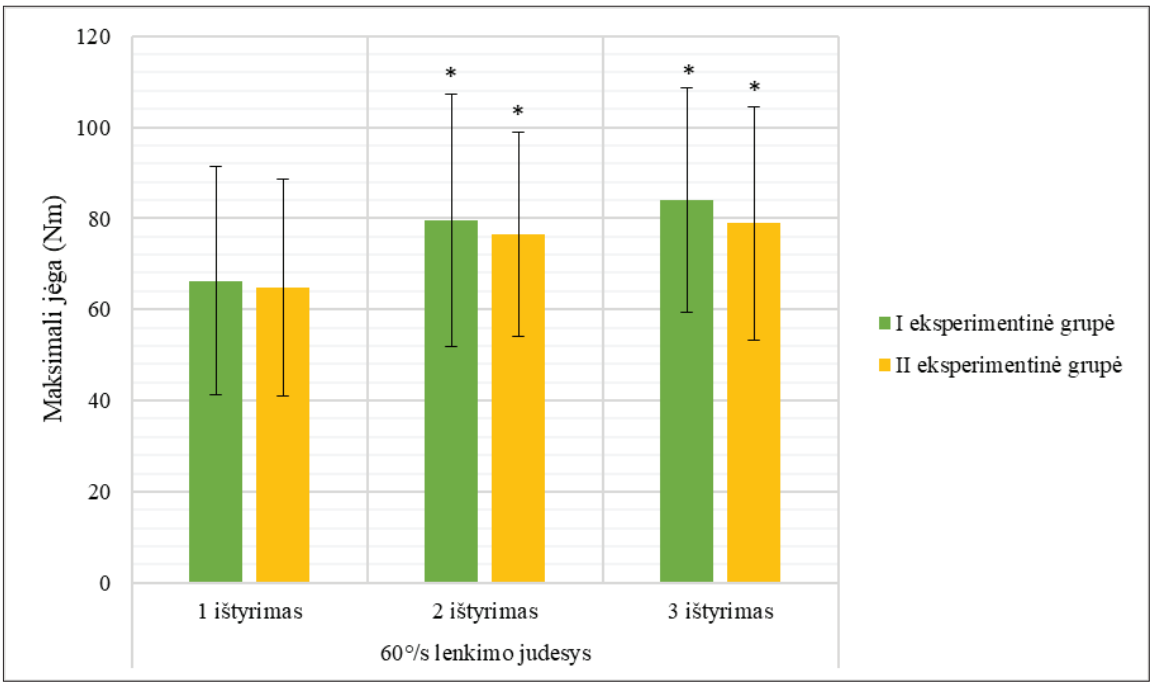

2 pav. I ir II eksperimentinių grupių maksimalios jëgos pokytis, atliekant kelio sąnario lenkimo judesị 600/s kampiniu greičiu.

$* p \leq 0,05$, lyginant su 1 tyrimu. izokinetiniu dinamometru „Biodex multi-joint system 4-pro“".

Statistinei duomenų analizei buvo naudojamas programinis paketas MS Excel 2016 (grafiniam duomenų apipavidalinimui) ir SPSS programa (17.0 versija). Statistinès duomenų analizès metu buvo apskaičiuoti aritmetiniai vidurkiai $(\overline{\overline{\mathrm{x}}})$, standartiniai nuokrypiai (SN). Siekiant nustatyti, ar duomenys pasiskirstę pagal normalụji skirstinị, buvo naudojamas Shapiro-Wilk kriterijus. Reikšmingumo lygmuo $\mathrm{p}$, esant normaliam skirstiniui, buvo skaičiuojamas pagal nesusietų ir susietų imčių Student $t$ kriterijų, o esant nenormaliam skirstiniui buvo naudojamas Mann-Whitney-Wilcoxon testas. Skirtumai tarp grupių buvo laikomi patikimais, kai $\mathrm{p} \leq 0,05$.

\section{Tyrimo rezultatai}

I ir II eksperimentinių grupių maksimalios jègos pokytis, atliekant kelio sąnario tiesimo judesi $60 \%$ sampinio greiči, pateiktas 1 paveiksle. Statistiškai reikšmingo skirtumo tarp dominuojančios ir nedominuojančios kojos maksimalios jëgos (niutonmetrais, $\mathrm{Nm}$ ) rodiklio nebuvo, todèl analizè atliekama naudojant tik dominuojančios kojos duomenis. Antrojo tyrimo metu I eksperimentinès grupès maksimali jejga, atliekant $60 \%$ s kampinio greičio kelio sąnario tiesimo judesį, buvo statistiškai reikšmingai didesné, nei pirmo ištyrimo metu, atitinkamai $156,6 \pm 26,44 \mathrm{Nm}$ ir $131,9 \pm 47,92 \mathrm{Nm}(\mathrm{p} \leq 0,05)$. Lyginant I eksperimentinès grupès maksimalios jëgos pokyti antrojo ir trečiojo tyrimo metu, atliekant $60 \%$ s kampinio greičio kelio sąnario tiesimo judesi, matyti, jog maksimali jèga turejo tendenciją didèti, tačiau skirtumas nebuvo statistiškai reikšmingas $(p>0,05)$. Trečiojo ty- 
rimo metu, I eksperimentinès grupès maksimali jejga, atliekant $60 \%$ sampinio greičio kelio sąnario tiesimo judesį, buvo statistiškai reikšmingai didesnè, nei pirmojo tyrimo metu, atitinkamai $175,3 \pm 42,58 \mathrm{Nm}$ ir $131,9 \pm 47,92 \mathrm{Nm}(\mathrm{p} \leq 0,05)$.

Antrojo tyrimo metu II eksperimentinès grupès maksimali jèga, atliekant $60 \%$ s kampinio greičio kelio sąnario tiesimo judesí, buvo statistiškai reikšmingai didesnè, nei pirmojo tyrimo metu, atitinkamai $158,6 \pm 37,62 \mathrm{Nm}$ ir $142,8 \pm 36,94$ $\mathrm{Nm}(\mathrm{p} \leq 0,05)$. Trečiojo tyrimo metu II eksperimentinès grupès maksimali jèga, atliekant $60 \%$ s kampinio greičio kelio sąnario tiesimo judesį, buvo statistiškai reikšmingai didesnè, nei antrojo tyrimo metu, atitinkamai $158,6 \pm 37,62 \mathrm{Nm}$ ir $167,8 \pm 39,53$ $\mathrm{Nm}(\mathrm{p} \leq 0,05)$. Trečiojo tyrimo metu II eksperimentinès grupès maksimali jèga, atliekant $60 \%$ s kampinio greičio kelio sąnario tiesimo judesį, buvo statistiškai reikšmingai didesnè, nei pirmojo tyrimo metu, atitinkamai $167,8 \pm 39,53 \mathrm{Nm}$ ir $142,8 \pm 36,94$ $\mathrm{Nm}(\mathrm{p} \leq 0,05)$.

Statistiškai reikšmingas skirtumas tarp I ir II eksperimentinių grupių maksimalios jègos, atliekant $60 \%$ s kampinio greičio kelio sąnario tiesimo judesi pirmojo, antrojo ir trečiojo tyrimo metu, nebuvo nustatytas $(\mathrm{p}>0,05)$.

I ir II eksperimentinių grupių maksimalios jejgos pokytis, atliekant kelio sąnario lenkimo judesi $60 \%$ s kampiniu greičiu, pateiktas 2 paveiksle. Statistiškai reikšmingo skirtumo tarp dominuojančios ir nedominuojančios kojos maksimalios jègos rodiklio nebuvo, todèl analizei naudoti tik dominuojančios kojos duomenys. Antrojo tyrimo metu I eksperimentinès grupès maksimali jèga, atliekant $60 \%$ s kampinio greičio kelio sąnario lenkimo judesị, buvo statistiškai reikšmingai didesnè, nei pirmojo tyrimo metu, atitinkamai $79,6 \pm 27,80 \mathrm{Nm}$ ir $66,2 \pm 25,03 \mathrm{Nm}(\mathrm{p} \leq 0,05)$. Lyginant I eksperimentinès grupès maksimalios jègos pokytị antrojo ir trečiojo tyrimo metu, atliekant $60 \%$ sampinio greičio kelio sąnario lenkimo judesí, matyti, jog maksimali jèga turèjo tendenciją didèti, tačiau skirtumas nebuvo statistiškai reikšmingas $(p>0,05)$. Trečiojo tyrimo metu, I eksperimentinès grupès maksimali jèga, atliekant $60 \%$ s kampinio greičio kelio sąnario lenkimo judesį, buvo statistiškai reikšmingai didesnè, nei pirmojo tyrimo metu, atitinkamai $83,9 \pm 24,66 \mathrm{Nm}$ ir $66,2 \pm 25,03 \mathrm{Nm}$ $(p \leq 0,05)$.

Antrojo tyrimo metu, II eksperimentinės grupès maksimali jèga, atliekant $60 \% \mathrm{~s}$

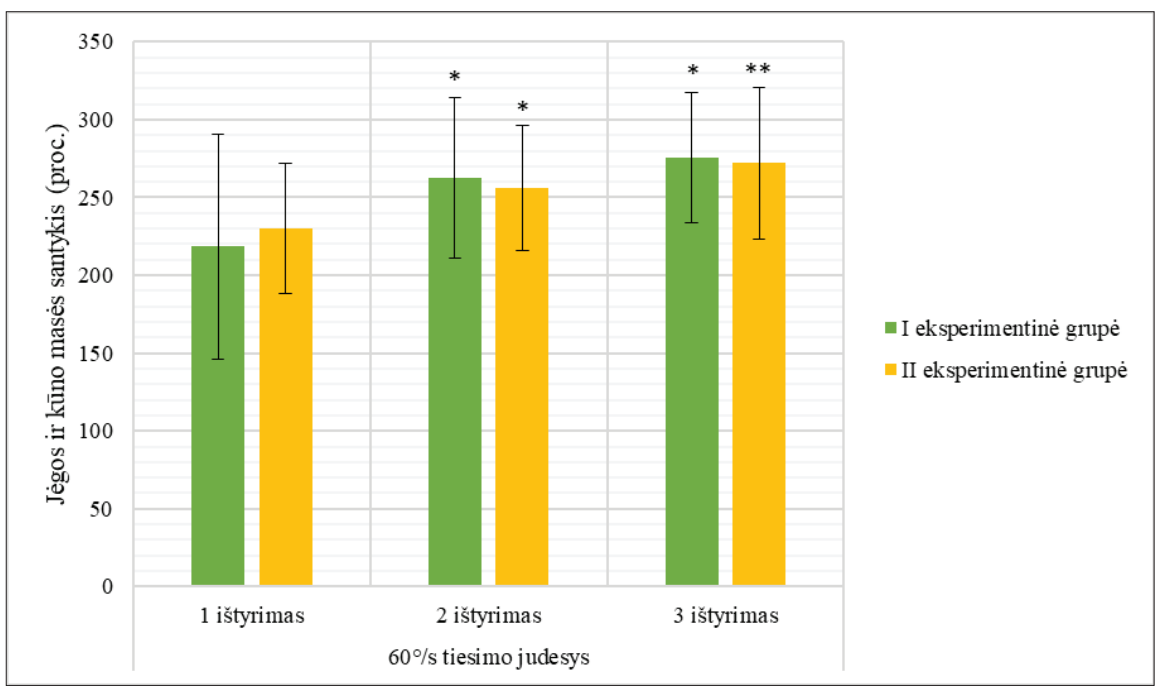

3 pav. I ir II eksperimentinių grupių jẻgos ir kūno masės santykio pokytis, atliekant kelio sąnario tiesimo judesi $60 \%$ s kampiniu greičiu.

* $p \leq 0,05$ lyginant su 1 tyrimu; ** $p \leq 0,05$ lyginant su 1 ir 2 tyrimais.

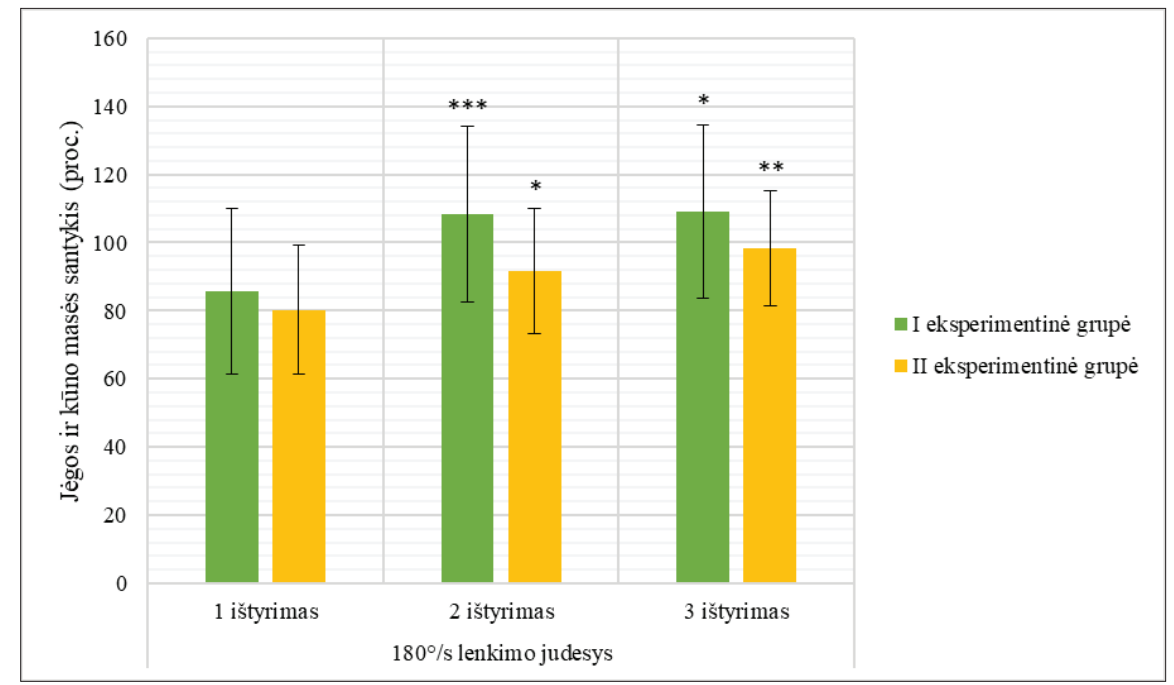

4 pav. I ir II eksperimentinių grupių jẻgos ir kūno masės santykio pokytis, atliekant kelio sąnario lenkimo judesi $180 \%$ s kampiniu greičiu.

${ }^{*} p \leq 0,05$, lyginant su 1 tyrimu; $* * p \leq 0,05$, lyginant su 1 ir 2 tyrimu; $* * * p \leq 0,05$, lyginant su 1 tyrimu ir II eksperimentine grupe 2 tyrimo metu. 
kampinio greičio kelio sąnario lenkimo judesį, buvo statistiškai reikšmingai didesnè, nei pirmojo tyrimo metu, atitinkamai $76,5 \pm 22,33 \mathrm{Nm}$ ir $64,8 \pm 23,76 \mathrm{Nm}$ $(\mathrm{p} \leq 0,05)$. Lyginant II eksperimentinès grupès maksimalios jègos pokyti antrojo ir trečiojo tyrimo metu, atliekant $60 \%$ sampinio greičio kelio sąnario lenkimo judesị, pastebèta, jog maksimali jèga turejjo tendenciją didèti, tačiau skirtumas nebuvo statistiškai reikšmingas $(\mathrm{p}>0,05)$. Trečiojo tyrimo metu, II eksperimentinès grupès maksimali jèga, atliekant $60 \%$ sampinio greičio kelio sąnario lenkimo judesį, buvo statistiškai reikšmingai didesnè, nei pirmojo tyrimo metu, atitinkamai $78,9 \pm 25,59$ $\mathrm{Nm}$ ir $64,8 \pm 23,76 \mathrm{Nm}(\mathrm{p} \leq 0,05)$.

Statistiškai reikšmingo skirtumo tarp I ir II eksperimentinių grupių maksima-

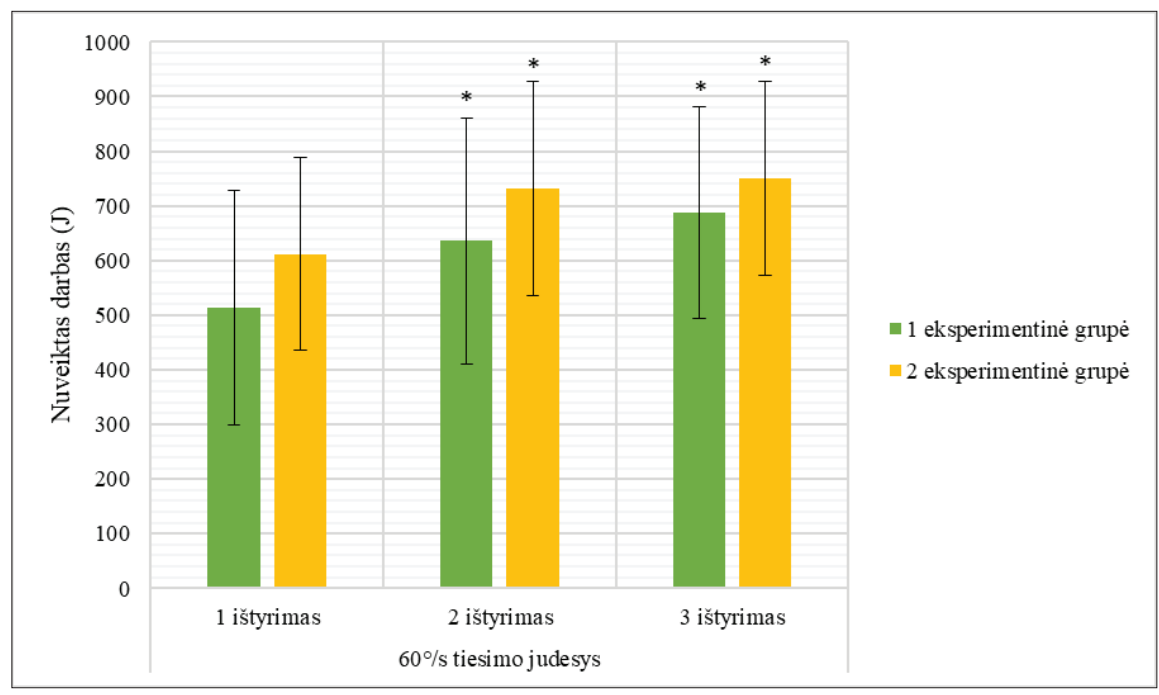

5 pav. I ir II eksperimentinių grupių nuveikto darbo pokytis, atliekant kelio sąnario tiesimo judesị $60^{\circ}$ s kampiniu greičiu.

$* p \leq 0,05$, lyginant su 1 tyrimu.

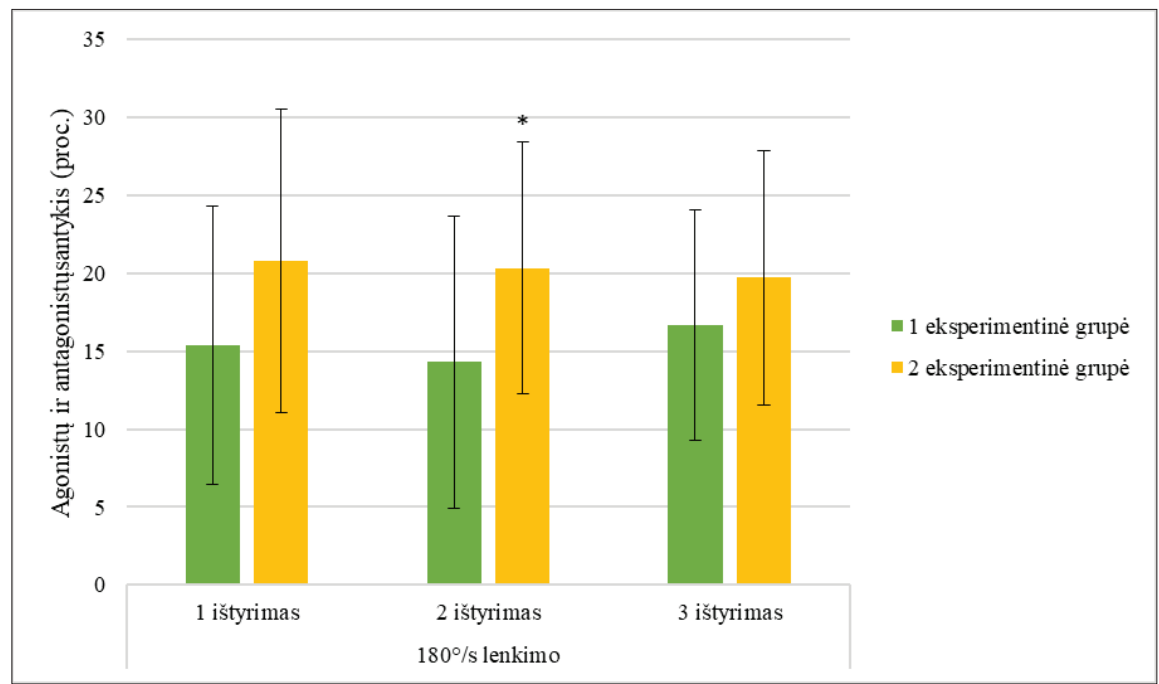

6 pav. I ir II eksperimentinių grupių agonistų ir antagonistų santykio pokytis, atliekant kelio sąnario lenkimo judesị $180 \%$ s kampiniu greičiu.

${ }^{*} p \leq 0,05$, lyginant su I eksperimentine grupe 2 tyrimo metu. lios jègos, atliekant $60 \%$ sampinio greičio kelio sąnario lenkimo judesį pirmojo, antrojo ir trečiojo tyrimo metu, nenustatyta $(p>0,05)$.

I ir II eksperimentinių grupių jègos ir kūno masès santykio pokytis, atliekant kelio sąnario tiesimo judesi $60 \%$ sampiniu greičiu, pateiktas 3 paveiksle. Statistiškai reikšmingo skirtumo tarp dominuojančios ir nedominuojančios kojos jègos ir kūno masès santykio rodiklio nebuvo, todèl analizè atliekama naudojant tik dominuojančios kojos duomenis. Antrojo tyrimo metu I eksperimentinès grupès jègos ir kūno masès santykis, atliekant $60 \%$ sampinio greičio kelio sąnario tiesimo judesį, buvo statistiškai reikšmingai didesnis, nei pirmojo tyrimo metu, atitinkamai 262,6 $\pm 51,86$ proc. ir $218,6 \pm 72,24$ proc. $(\mathrm{p} \leq 0,05)$. Lyginant I eksperimentinès grupès jègos ir kūno masès santykio pokytį antrojo ir trečiojo tyrimo metu, atliekant $60 \% \mathrm{~s} \mathrm{kam-}$ pinio greičio kelio sąnario tiesimo judesị, matyti, jog jègos ir kūno masès santykis turejo tendenciją didèti, tačiau skirtumas nebuvo statistiškai reikšmingas $(\mathrm{p}>0,05)$. Trečiojo tyrimo metu I eksperimentinès grupès jègos ir kūno masès santykis, atliekant $60 \%$ kampinio greičio kelio sąnario tiesimo judesi, buvo statistiškai reikšmingai didesnis, nei pirmojo tyrimo metu, atitinkamai $275,6 \pm 42,00$ proc. ir $218,6 \pm 72,24$ proc. $(\mathrm{p} \leq 0,05)$.

Antrojo tyrimo metu II eksperimentinès grupès jègos ir kūno masès santykis, atliekant $60 \%$ s kampinio greičio kelio sąnario tiesimo judesí, buvo statistiškai reikšmingai didesnis, nei pirmojo tyrimo metu, atitinkamai $256,1 \pm 40,54$ proc. ir $230,1 \pm 41,92$ proc. $(\mathrm{p} \leq 0,05)$. Trečiojo tyrimo metu II eksperimentinès grupès jègos ir kūno masès santykio rodiklis, atliekant $60 \%$ 
kampinio greičio kelio sąnario tiesimo judesį, buvo statistiškai reikšmingai didesnis, nei antrojo tyrimo metu, atitinkamai $272,0 \pm 48,69$ proc. ir $256,1 \pm 40,54$ proc. $(p \leq 0,05)$. Trečiojo tyrimo metu II eksperimentinès grupès jègos ir kūno masès santykis, atliekant $60 \%$ s kampinio greičio kelio sąnario tiesimo judesį, buvo statistiškai reikšmingai didesnis, nei pirmojo tyrimo metu, atitinkamai $272,0 \pm 48,69$ proc. ir $230,1 \pm 41,92$ proc. $(\mathrm{p} \leq 0,05)$.

Statistiškai reikšmingo skirtumo tarp I ir II eksperimentinių grupių jègos ir kūno masès santykio, atliekant $60 \%$ kampinio greičio kelio sąnario tiesimo judesí, pirmojo, antrojo ir trečiojo tyrimo metu nenustatyta $(\mathrm{p}>0,05)$.

I ir II eksperimentinių grupių jègos ir kūno masès santykio pokytis, atliekant kelio sąnario lenkimo judesį $180^{\circ} / \mathrm{s}$ kampiniu greičiu, pateiktas 4 paveiksle. Statistiškai reikšmingo skirtumo tarp dominuojančios ir nedominuojančios kojos jègos ir kūno masès santykio rodiklio nebuvo, todèl analizė atlikta naudojant tik dominuojančios kojos duomenis. Antrojo tyrimo metu I eksperimentinès grupès jègos ir kūno masès santykis, atliekant $180 \%$ s kampinio greičio kelio sąnario lenkimo judesį, buvo statistiškai reikšmingai didesnis, nei pirmojo tyrimo metu, atitinkamai $108,4 \pm 25,85$ proc. ir $85,7 \pm 24,18$ proc. $(\mathrm{p} \leq 0,05)$. Lyginant I eksperimentinès grupès jègos ir kūno masès santykio pokyti antrojo ir trečiojo tyrimo metu, atliekant $180 \%$ s kampinio greičio kelio sąnario lenkimo judesį, matyti, jog jègos ir kūno masès santykis nepakito $(\mathrm{p}>0,05)$. Trečiojo tyrimo metu I eksperimentinès grupès jëgos ir kūno masès santykis, atliekant $180^{\circ} / \mathrm{s} \mathrm{kam-}$ pinio greičio kelio sąnario lenkimo judesį, buvo statistiškai reikšmingai didesnis, nei pirmojo tyrimo metu, atitinkamai $109,0 \pm 25,39$ proc. ir $85,7 \pm 24,18$ proc. $(\mathrm{p} \leq 0,05)$.

Antrojo tyrimo metu II eksperimentinès grupès jègos ir kūno masès santykis, atliekant $180 \%$ s kampinio greičio kelio sąnario lenkimo judesį, buvo statistiškai reikšmingai didesnis, nei pirmojo tyrimo metu, atitinkamai $91,6 \pm 18,40$ proc. ir $80,2 \pm 18,95$ proc. $(\mathrm{p} \leq 0,05)$. Trečiojo tyrimo metu II eksperimentinès grupès jègos ir kūno masès santykio rodiklis, atliekant $180^{\circ} / \mathrm{s}$ kampinio greičio kelio sąnario lenkimo judesį, buvo statistiškai reikšmingai didesnis, nei antrojo tyrimo metu, atitinkamai $98,3 \pm 16,94$ proc. ir $91,6 \pm 18,40$ proc. ( $p \leq 0,05)$. Trečiojo tyrimo metu II eksperimentinès grupès jëgos ir kūno masès santykis, atliekant $180 \%$ s kampinio greičio kelio sąnario lenkimo judesį, buvo statistiškai reikšmingai didesnis, nei pirmojo tyrimo metu, atitinkamai $98,3 \pm 16,94$ proc. ir $80,2 \pm 18,95$ proc. $(\mathrm{p} \leq 0,05)$.

Antrojo tyrimo metu I eksperimentinès grupès jègos ir kūno masès santykis, atliekant $180^{\circ} / \mathrm{s}$ kampinio greičio kelio sąnario lenkimo judesį, buvo statistiškai reikšmingai didesnis, nei II eksperimentinès grupès, atitinkamai 108,4 $\pm 25,85$ proc. ir $91,6 \pm 18,40$ proc. $(\mathrm{p} \leq 0,05)$.
I ir II eksperimentinių grupių nuveikto darbo pokytis, atliekant $60 \%$ sampinio greičio kelio sąnario tiesimo judesi, pateiktas 5 paveiksle. Statistiškai reikšmingo skirtumo tarp dominuojančios ir nedominuojančios kojos nuveikto darbo rodiklio nebuvo, todèl analizè atlikta naudojant tik dominuojančios kojos duomenis. Antrojo tyrimo metu I eksperimentinès grupès nuveiktas darbas, atliekant $60 \%$ s kampinio greičio kelio sąnario tiesimo judesi, buvo statistiškai reikšmingai didesnis, nei pirmojo tyrimo metu, atitinkamai $635,4 \pm 225,26$ $\mathrm{J}$ ir 513,1 $\pm 213,97 \mathrm{~J}(\mathrm{p} \leq 0,05)$. Lyginant I eksperimentinès grupès nuveikto darbo pokytị antrojo ir trečiojo tyrimo metu, atliekant $60 \%$ sampinio greičio kelio sąnario tiesimo judesį, matyti, jog nuveiktas darbas turèjo tendenciją didèti, tačiau skirtumas nebuvo statistiškai reikšmingas $(p>0,05)$. Trečiojo tyrimo metu I eksperimentinès grupès nuveiktas darbas, atliekant $60 \%$ s kampinio greičio kelio sąnario tiesimo judesį, buvo statistiškai reikšmingai didesnis, nei pirmojo tyrimo metu, atitinkamai $688,0 \pm 194,23 \mathrm{~J}$ ir 513,1 $\pm 213,97 \mathrm{~J}(\mathrm{p} \leq 0,05)$.

Antrojo tyrimo metu II eksperimentinès grupès nuveiktas darbas, atliekant $60 \%$ s kampinio greičio kelio sąnario tiesimo judesį, buvo statistiškai reikšmingai didesnis, nei pirmojo tyrimo metu, atitinkamai $731,6 \pm 196,24 \mathrm{~J}$ ir $612,1 \pm 176,17$ $\mathrm{J}(\mathrm{p} \leq 0,05)$. Lyginant II eksperimentinès grupès nuveikto darbo pokytị antrojo ir trečiojo tyrimo metu, atliekant $60 \%$ kampinio greičio kelio sąnario tiesimo judesį, matyti, jog nuveiktas darbas turejjo tendenciją didèti, tačiau skirtumas nebuvo statistiškai reikšmingas ( $\mathrm{p}>0,05)$. Trečiojo tyrimo metu II eksperimentinès grupès nuveiktas darbas, atliekant $60 \%$ s kampinio greičio kelio sąnario tiesimo judesį, buvo statistiškai reikšmingai didesnis, nei pirmojo tyrimo metu, atitinkamai $750,5 \pm 177,54 \mathrm{~J}$ ir $612,1 \pm 176,17 \mathrm{~J}(\mathrm{p} \leq 0,05)$.

Statistiškai reikšmingo skirtumo tarp I ir II eksperimentinių grupių nuveikto darbo, atliekant $60 \%$ s kampinio greičio kelio sąnario tiesimo judesį, pirmojo, antrojo ir trečiojo tyrimo metu nenustatyta $(\mathrm{p}>0,05)$.

I ir II eksperimentinių grupių agonistų ir antagonistų santykio pokytis, atliekant kelio sąnario lenkimo judesi $180 \%$ s kampiniu greičiu, pateiktas 6 paveiksle. Statistiškai reikšmingo skirtumo tarp dominuojančios ir nedominuojančios kojos agonistų ir antagonistų santykio rodiklio nebuvo, todèl analizė atlikt naudojant tik dominuojančios kojos duomenis. Lyginant I eksperimentinès grupès agonistų ir antagonistų santykio pokyti pirmojo ir antrojo tyrimų metu, atliekant 180 \% kampinio greičio kelio sąnario lenkimo judesį, matyti, jog agonistų ir antagonistų santykis turëjo tendenciją mažèti, antrojo ir trečiojo tyrimų metu - didèti, tačiau skirtumai nebuvo statistiškai reikšmingi $(p>0,05)$. Lyginant I eksperimentinès grupès agonistų ir antagonistų santykio pokytị pirmojo ir trečiojo tyrimų metu, atliekant $180^{\circ} / \mathrm{s}$ kampinio greičio kelio sąnario lenkimo judesį, matyti, jog agonistų ir 
antagonistų santykis turèjo tendenciją didèti, tačiau skirtumai nebuvo statistiškai reikšmingi $(\mathrm{p}>0,05)$.

Lyginant II eksperimentinès grupès agonistų ir antagonistų santykio pokyti pirmojo ir antrojo, antrojo ir trečiojo bei pirmojo ir trečiojo tyrimų metu, atliekant $180^{\circ} / \mathrm{s}$ kampinio greičio kelio sąnario lenkimo judesį, matyti, jog agonistų ir antagonistų santykis nepakito $(\mathrm{p}>0,05)$.

Antrojo tyrimo metu II eksperimentinès grupès agonistu ir antagonistų santykis, atliekant $180 \%$ s kampinio greičio kelio sąnario lenkimo judesį, buvo statistiškai reikšmingai didesnis, nei I eksperimentinès grupès, atitinkamai 20,3 $\pm 8,09$ proc. ir $14,3 \pm 9,40$ proc. $(\mathrm{p} \leq 0,05)$.

\section{Rezultatų aptarimas}

Mokslinejje literatūroje nagrinejjama, kokia pratimų programa ir koks krūvio dozavimas yra efektyviausias, siekiant padidinti raumenų jègą ir ištvermę. J. Indriūnienès ir bendraautorių atlikto tyrimo rezultatai atskleidè, kad izokinetiné treniruote buvo efektyvesné, nei tradicinių jègos pratimų programa. Nustatyta, kad tiksliai dozuotos treniruotès, naudojant izokinetini dinamometrą, blauzdos lenkiamujų raumenų jẻgą padidino 18,50 proc., o ištvermę - 39,77 proc. [21]. T. Kaukẻno ir bendraautorių atlikto tyrimo rezultatai parodè, kad 21 dienos treniruočiu stovykla, taikant dozuotą fizinị krūvị, padidino raumenų galingumo rodiklius ir toleranciją laktatui, turèjo teigiamą poveikị biatlonininkų širdies ir kraujagyslių sistemos funkciniam pajëgumui, kraujo morfologinei sudèčiai [24]. Dozuotas aerobinio pobūdžio fizinis krūvis padidina mitochondrijų kiekị ir jų fermentų aktyvumą skeleto raumenyse bei raumenų oksidacinị pajėgumą. Taikant kombinuotą dozuotą fizinị krūvị (aerobinè treniruote ir pasipriešinimo pratimai) pastebimas skeleto raumenų oksidacinio ir glikolitinio pajègumo padidejjimas, o tai gerokai padidino raumenų jègą, ištvermę ir skerspjūvio plotą [90].

Šio tyrimo rezultatai parode, kad $150 \mathrm{~W}$ intensyvumo 30 minučių trukmės dozuotas fizinis krūvis, taikytas 3 kartus per savaitę, praejus dviem ir keturiems mènesiams, padidino II eksperimentinès grupés skeleto raumenu jègą ir dinaminę ištvermę $(\mathrm{p} \leq 0,05)$, tačiau agonistu ir antagonistų santykis tyrimo eigoje nepakito. Analizuojant II eksperimentinès grupès skeleto raumenų jègos ir ištvermès rodiklių rezultatus, tarp antrojo ir trečiojo tyrimų nerasta statistiškai reikšmingų pokyčiu $(\mathrm{p}>0,05)$. Analizuojant I eksperimentinès grupès dozuoto fizinio krūvio poveikį, po dviejų mènesių intervencijos pastebètas skeleto raumenų jègos ir dinaminès ištvermès padidejimas $(p \leq 0,05)$. Pastebèta, jog agonistų ir antagonistų santykis tyrimo eigoje nepakito, o tai rodo, kad dozuoto fizinio krūvio taikymo metu simetriškai treniravosi raumenu grupès, tokiu būdu mažinant traumos tikimybę. Po dviejų mènesių intervencijos papildomai du mènesius laikantis fizinio aktyvumo rekomendacijų, I eksperimentinès grupès pasiekti skeleto raumenu jègos ir dinaminès ištvermès rezultatai neregresavo. Lyginant I ir II eksperimentiniu grupių tyrimo eigoje pasiektus rezultatus, pastebėta, jog I eksperimentinès grupès jègos ir kūno masès santykis antrojo tyrimo metu buvo didesnis, nei II eksperimentinès grupès $(p \leq 0,05)$. Pastebèta, kad II eksperimentinès grupès agonistu ir antagonistu santykis pirmojo ir antrojo tyrimo metu buvo didesnis, nei I eksperimentinès grupès $(p \leq 0,05)$, tačiau stebint kitus jègos ir dinaminès ištvermès rodiklius, skirtumu tarp šių grupių rasti nepavyko.

Savaiminè skeleto raumenų sistemos regresija yra viena svarbiausių klinikinès medicinos ir reabilitacijos medicinos mokslinių tyrimų temų. S. Zhang ir bendraautorių atlikto tyrimo rezultatai įrode, kad fizinis pasyvumas sukelia skeleto raumenų atrofiją, gerokai sumažina skeleto raumenų masès ir kūno svorio santykị bei skeleto raumenų skaidulu skerspjūvio plotą [27]. Nepriklausomai nuo to, ar asmuo yra profesionalus sportininkas, ar tiesiog reguliariai sportuoja, fizinio aktyvumo nutraukimo poveikis raumenų rodikliams ir struktūrinei sistemai po 10-28 dienų pasireiškia pastebimai sumažejjusia raumenų jèga ir ištverme, ịskaitant greiț ir vikrumą, mobilumą, gebejimą staigiai sustoti bei koordinacijos praradimą [29]. Analizuojant mūsų atlikto tyrimo rezultatus pastebèta, jog laikantis fizinio aktyvumo rekomendacijų, galima sẻkmingai išsaugoti pasiektus skeleto raumenų jẻgos ir dinaminès ištvermès rodiklių rezultatus.

\section{Išvados}

1. Dviejų mènesių trukmès dozuoto fizinio krūvio taikymas vienodai padidino kojų raumenų jègą ir dinaminę ištvermę agonistams ir antagonistams. Du mènesius namuose laikantis fizinio aktyvumo rekomendacijų, pasiekti kojų raumenų jègos ir dinaminès ištvermès rezultatai neregresavo.

2. Keturių mėnesių trukmès intervencijos taikymas vienodai padidino kojų raumenų jẻgą ir dinaminę ištvermę agonistams ir antagonistams, tačiau nuo antrojo intervencijos mėnesio kojų raumenų jègos ir dinaminès ištvermès didèjimo tendencija nebuvo statistiškai reikšminga.

3. Ir keturių mènesių trukmès dozuoto fizinio krūvio taikymas, ir dviejų mėnesių intervencijos taikymas su tęstiniu dviejų mėnesių fizinio aktyvumo rekomendacijų vykdymu namuose, vienodai padidino kojų raumenų jègos ir dinaminès ištvermès rodiklius.

\section{Literatūra}

1. Mounesan L, Sepidarkish M, Hosseini H, Ahmadi A, Ardalan G, Kelishadi R. Policy brief for promoting physical activity among Iranian adolescents. J Isf Med School 2013; 31(233):510-20.

2. Corder K, Winpenny E, Love R, Brown H. White M, Sluijs E. 
Change in physical activity from adolescence to early adulthood: a systematic review and metaanalysis of longitudinal cohort studies. Br J Sports Med 2019; 53(5):496-503.

https://doi.org/10.1136/bjsports-2016-097330

3. European Commission. Lithuanian physical activity factsheet, 2014. http://www.euro.who.int/_data/assets/pdf_ file/0008/288116/LITHUANIA-Physical-Activity-Factsheet. pdf

4. Penning A, Okely A, Trost S, Salmon JC, Batterham M, Howard SP. Acute effects of reducing sitting time in adolescents: a randomized cross-over study. Br J Sports Med 2017; 17:657-68. https://doi.org/10.1186/s12889-017-4660-6

5. Borhani M, Sadeghi R, Shojaeizadeh D, Harandi TF, Vakili MA. Teenage girls' experience of the determinants of physical activity promotion: a theory based qualitative content analysis. El Phys 2017; 9(8):5075-82. https://doi.org/10.19082/5075

6. Poitras VJ, Gray CE, Borghese MM, Carson V, Chaput JP, Janssen I, Katzmarzyk PT, Pate RR, Connor GS, Kho ME. Systematic review of the relationships between objectively measured physical activity and health indicators in school aged children and youth. Appl Physiol Nutr Metab 2016; 41(8):197-239. https://doi.org/10.1139/apnm-2015-0663

7. Cameron JD, Sigal RJ, Kenny GP, Alberga AS, Prud'homme D, Phillips P, Doucette S, Goldfield G. Body composition and energy intake skeletal muscle mass is the strongest predictor of food intake in obese adolescents. Appl Phys, Nutr Met 2016; 41(6): 611-7.

https://doi.org/10.1139/apnm-2015-0479

8. Smith JJ, Eather N, Morgan PJ, Plotnikoff RC, Faigenbaum AD, Lubans DR. The health benefits of muscular fitness for children and adolescents: a systematic review and metaanalysis. Sports Med 2014; 44(9):1209-23. https://doi.org/10.1007/s40279-014-0196-4

9. Adams V, Reich B, Uhlemann M, Niebauer J. Molecular effects of exercise training in patients with cardiovascular disease: focus on skeletal muscle, endothelium, and myocardium. Am J Phys - Heart Circ Phys 2017; 313(1):72-88.

https://doi.org/10.1152/ajpheart.00470.2016

10. Vlachopoulos D, Barker AR, Williams CA, Knapp KM, Metcalf BS, Gracia-Marco L. Effect of a program of short bouts of exercise on bone health in adolescents involved in different sports: the PRO-BONE study protocol. BMC Publ Health 2015;15(2):361-71.

https://doi.org/10.1186/s12889-015-1633-5

11. Kim S, Nettlefold L, Gabel L, Tan VP, Macdonald HM. Influence of physical activity on bone strength in children and adolescents: a systematic review and narrative synthesis. J Bone MinRes 2014; 29(10):2161-81. https://doi.org/10.1002/jbmr.2254

12. Vlachopoulos D, Gracia-Marco L, Barker AR, Huybrechts I, Moreno LA, Mouratidou T. Bone health: the independent and combined effects of calcium, vitamin $\mathrm{D}$ and exercise in children and adolescents. Royal SocChem 2016; 32(7):530-46.

https://doi.org/10.1039/9781782622130-00530

13. Quka N, Stratoberdha D, Selenica R. Risk factors of poor posture in children and its prevalence. AcJ Int St 2015; 4(3):97-102. https://doi.org/10.5901/ajis.2015.v4n3p97

14. Craggs C, Corder K, Sluijs E, Griffin SJ. Determinants of change in physical activity in children and adolescents: a sistematic review. Am J Prev Med 2011; 40(6):645-58.

https://doi.org/10.1016/j.amepre.2011.02.025

15. Furian TC, Rapp W, Eckert S, Wild M, Betsch M. Spinal posture and pelvic position in three hundred forty five elementary school children: a rasterstereographic pilot study. Orthop Rev 2013; 5(7):29-33.

https://doi.org/10.4081/or.2013.e7

16. Mitova S, Popova D, Gramatikova M. Postural disorders and spinal deformities in children at school age. System for screening, examination, prevention and treatment. Ac Phys Ed Sport 2014; 4(2):172-7.

17. Best K, Ball K, Zarnowiecki D, Stanley R, Dollman J. In search of consistent predictors of children's physical activity. Int J Environ Res Public Health 2017;14(10):1258-72.

https://doi.org/10.3390/ijerph14101258

18. Kairiūkštienė Ž., Velička D., Poderys J. Širdies ir kraujagyslių sistemos adaptacija sveikatą stiprinančiose pratybose, taikant jẻgos ugdymo pratimų arba šiaurietiškojo ejjimo užduotis. Sporto mokslas, 2016;1(83):48-54.

19. Gondim OS, Camargo VT, Gutierrez FA, Martins PF, Passos ME, Momesso CM, Santos VC, Gorjão R, Pithon-Curi TC, Cury-Boaventura MF. Benefits of regular exercise on inflammatory and cardiovascular risk markers in normal weight, overweight. J PLOS ONE E 2015; 10(10):1371-85. https://doi.org/10.1371/journal.pone.0140596

20. Zoladz JA, Grassi B, Rossiter HB. Skeletal muscle fatigue and decreased efficiency: two sides of the same coin? ExSport Sc Rev 2015;43(2):75-83. https://doi.org/10.1249/JES.0000000000000043

21. Indriūnienė J., Juocevičius A., Jamontaitė I.E., Muntianaitė I. Izokinetinių ir tradicinių jègos treniruočių įtaka moterų blauzdos lenkiamujų raumenų funkcinei būklei. Sveikatos mokslai, 2016;26(3):14-9.

https://doi.org/10.5200/sm-hs.2016.038

22. Dadelienė R., Daunytė A. Skirtingų aerobinio fizinio aktyvumo programų poveikis asmenų, kuriems atlikta aortos koronarinių jungčių operacija, funkciniam pajėgumui. Visuomenès sveikata, 2018;1(80):80-5.

23. Diment BC, Fortes MB, Edwards JP, Hanstock HG, Ward MD, Dunstall HM, Friedmann PS, Walsh NP. Exercise intensity and duration effects on in vivo immunity. Med Sc Sports Ex 2015;3(6):1-9.

https://doi.org/10.1249/MSS.0000000000000562 
24. Kaukėnas T., Sabaliauskas S. Biatlonininkų raumenų galingumo ugdymas aukštikalnių sąlygomis. Sporto mokslas, 2016;4(86):65-72.

https://doi.org/10.15823/sm.2016.44

25. Ališauskienė R., Milašius K. Esminiai jaunųų, 16-18 metų, plento dviratininkų rengimo bruožai. Pedagogika, 2015;117(1):143-56.

https://doi.org/10.15823/p.2015.074

26. Rudrappa SS, Wilkinson DJ, Greenhaff PL, Smith K, Idris I, Atherton PJ. Human skeletal muscle disuse atrophy: effects on muscle protein synthesis, breakdown, and insulin resistance-a qualitative review. Front Physiol 2016;7(1):361-71.

https://doi.org/10.3389/fphys.2016.00361

27. Zhang SF, Zhang Y, Chen BLN. Physical inactivity induces the atrophy of skeletal muscle of rats through activating AMPK/FoxO3 signal pathway. Eur Rev Med Pharm Sci 2018;22(5):199-209.

28. Vigels A, Gram M, Wiuff C, Andersen JL, Helge JW, Dela F. Six weeks' aerobic retraining after two weeks' immobilization restores leg lean mass and aerobic capacity but does not fully rehabilitate leg strength in young and older men. J RehabMed 2015; 47(2): 552-60.

https://doi.org/10.2340/16501977-1961

29. Mala Vaki CJ, Sakkas GK, Mitrou GI, Kal A, Stefanidis I, Myburgh KH, Karatzaferi C. Skeletal muscle atrophy: diseaseinduced mechanisms may mask disuse atrophy. J Muscle Res Cell Motil 2015;36(11):405-21.

https:/doi.org/10.1007/s10974-015-9439-8

\section{THE EFFECT OF MEASURED PHYSICAL ACTIVITY ON ADOLESCENTS MUSCULOSKELETAL SYSTEM T. Aukštikalnis, V. Radzevič, E. Godliauskienė, R. Urbanavičè, J. Kairys, J. Raistenskis}

Keywords: measured physical activity, veloergometer, adolescents, skeletal muscle system.

Summary

The research aim was to investigate the effect of measured physical activity on the musculoskeletal system. The study was conducted from March 2018 to January 2019 in Vilnius Senvagès Gymnasium and Children's Hospital, Affiliate of Vilnius University Hospital Santaros clinics. The study included adolescents aged 14 to 17 who voluntarily agreed to participate. The sample consisted of 46 students, of whom 27 were girls and 19 were boys. The isokinetic Biodex Multi-Joint System - PRO4 was used in order to evaluate the muscle strength and dynamic endurance and the medical scales were used to determine height and body mass of students. The intervention of measured physical activity was applied using a veloergometer. MS Excel 2016 and SPSS Windows 17.0 were used for statistical data analysis.

Results: the use of dosed physical exercise for two months increased the maximum force, strength to body weight ratio as well as total work $(\mathrm{p} \leq 0.05)$. After two months of intervention, additionally following the physical activity guidelines for two months did not reverse any gains achieved on skeletal muscles' strength and dynamic endurance $(p \leq 0.05)$. Correspondingly, the use of dosed physical exercise for four months also increased the skeletal muscle strength and dynamic endurance $(\mathrm{p} \leq 0.05)$, however after the second month of intervention the growth was not statistically significant $(p>0.05)$. The use of two and four month interventions did not change the ratio of agonists and antagonists $(p>$ 0.05). Comparing the effect of physical exercise on both subject groups, a higher strength to body weight ratio was observed after the two month intervention, compared to the group which was subject to a four month intervention $(p \leq 0.05)$. Similarly, the ratio of agonists to antagonists was higher in the first and second trials of the group which was subject to a four month intervention, than in the two month intervention group $(\mathrm{p} \leq 0.05)$, however there were no differences in other indicators of strength and dynamic endurance $(\mathrm{p}>0.05)$

Conclusions: the use of dosed physical exercise for two months equally increased skeletal muscle strength and dynamic endurance for both agonists and antagonists. Following the physical activity guidelines for two months at home did not reverse the gains achieved on skeletal muscles' strength and dynamic endurance. The use of dosed physical exercise for four months increased the skeletal muscle strength and dynamic endurance $(p \leq 0.05)$, however after the second month of intervention the growth was not statistically significant $(\mathrm{p}<0.05)$. Both the use of dosed physical exercise for two months together with following the physical activity guidelines at home for two months and the use of physical exercise for four months equally increased the indicators of muscle strength and dynamic endurance.

Correspondence to: tomas.aukstikalnis @santa.lt

Gauta 2019-11-21 